\title{
DIGLOSIA
}

Volume 3, Nomor 1, Februari 2020, Halaman 46-52

p-ISSN 2615-725X (Print) e-ISSN 2615-8655 (Online)

http://diglosiaunmul.com/index.php/diglosia/article/view/29

\section{PENGEMBANGAN BAHAN AJAR MENULIS TEKS CERPEN BERDASARKAN TEKNIK STORYBOARD PADA SISWA KELAS XI SMA}

\section{The Development of Writing Short Story Teaching Materials Based on Storyboard Technique for the Eleventh Grade Students}

\author{
Ika Novita ${ }^{1, *}$, M. Siddik ${ }^{2}$, Asnan Hefni ${ }^{3}$ \\ ${ }^{1}$ Magister Pendidikan Bahasa dan Sastra Indonesia, FKIP, Universitas Mulawarman \\ ${ }^{2,3}$ Universitas Mulawarman \\ Pos-el korespondensi: ikanovita736@gmail.com
}

\begin{abstract}
The purpose of this study was to develop teaching materials for writing short stories based on storyboarding techniques in class XI high school students, to know the feasibility of teaching materials for writing short stories based on storyboarding techniques in class XI high school students and to know the effectiveness of short story writing teaching materials based on storyboard techniques in class XI High school. This research is a research development or Research \& Development (R\&D). Research and Development is a research method used to produce certain products and test the effectiveness of products in the form of teaching materials to write short stories based on storyboarding techniques for class XI high school students. This development research resulted in the feasibility of the product being developed, a validation test involving media expert lecturers with an average score of 4.5 and Indonesian language professors with an average score of 4.66 and trials on students with an average score of 4, 45 with very good criteria. The eligibility criteria for teaching materials developed with a percentage of eligibility of $89 \%$, the teaching material for writing short stories based on storyboarding techniques for class XI high school students is very feasible to use. To achieve the objectives of teaching and learning activities must be done efficiently in its implementation to be effective and efficient. The feasibility assessment of this module includes four aspects namely, the content/ material aspect, the presentation aspect, the language aspect and the graphic aspect.
\end{abstract}

Keywords: development of teaching materials, writing short stories, storyboarding techniques

Abstrak: Tujuan penelitian ini adalah untuk mengembangkan bahan ajar menulis teks cerpen berdasarkan teknik storyboard pada siswa kelas XI SMA, untuk mengetahui kelayakan bahan ajar menulis teks cerpen berdasarkan teknik storyboard pada siswa kelas XI SMA, dan untuk mengetahui keefektifan bahan ajar menulis cerpen berdasarkan teknik storyboard di kelas XI SMA. Penelitian ini merupakan penelitian pengembangan atau Research \& Development (R\&D). Research and Development adalah metode penelitian yang digunakan untuk menghasilkan produk tertentu dan menguji keefektifan produk berupa bahan ajar menulis teks cerpen berdasarkan teknik storyboard untuk siswa kelas XI SMA. Penelitian pengembangan ini menghasilkan kelayakan produk yang dikembangkan, dilakukan uji validasi yang melibatkan dosen ahli media dengan skor rata-rata 4,5 dan dosen ahli Bahasa Indonesia dengan skor rata-rata 4,66 serta uji coba pada siswa dengan skor rata-rata 4,45 dengan kriteria sangat baik. Kriteria kelayakan bahan ajar yang dikembangkan dengan persentase kelayakan sebesar $89 \%$, maka bahan ajar menulis teks cerpen berdasarkan teknik storyboard untuk siswa kelas XI SMA sangat layak digunakan. Untuk mencapai tujuan kegiatan belajar mengajar harus dilakukan secara efisien dalam implementasinya bersifat efektif dan efisien. Penilaian kelayakan modul ini meliputi empat aspek, yaitu aspek isi/materi, aspek penyajian, aspek bahasa dan aspek kegrafikan.

Kata kunci: pengembangan bahan ajar, menulis cerpen, teknik storyboard 


\section{A. PENDAHULUAN}

Pembelajaran menulis cerpen di sekolah termasuk salah satu dari kompetensi pembelajaran menulis sastra. Standar isi pembelajaran menulis cerpen tidak hanya menuntut siswa memahami tetapi siswa juga dituntut untuk memproduksi karya sastra. Menulis cerpen merupakan keterampilan yang produktif dan ekspresif. Menulis sebagaimana berbicara, merupakan keterampilan yang produktif dan ekspresif. Perbedaannya, menulis merupakan komunikasi tidak bertatap muka (tidak langsung), sedangkan berbicara merupakan komunikasi tatap muka (langsung).

Cerpen adalah jenis karya sastra yang memaparkan kisah ataupun cerita tentang kehidupan manusia lewat tulisan pendek. cerpen juga bisa disebut sebagai karangan fiktif yang berisikan tentang sebagian kehidupan seseorang atau juga kehidupan yang diceritakan secara ringkas yang berfokus pada suatu tokoh saja. Dalam cerpen dipisahkan sepenggal kehidupan tokoh, yang penuh pertikaian, peristiwa yang mengharukan atau menyenangkan, dan mengandung kesan yang tidak mudah dilupakan (Kurniawan, 2012, hal. 49). Cerpen adalah sebuah karangan pendek yang mengisahkan seorang tokoh dengan sebuah masalah beserta penyelesaiannya. Sesuai namanya, cerpen haruslah pendek dan ringkas sehingga diberi nama cerita pendek. Cerita pendek cenderung kurang kompleks dibandingkan dengan novel. Cerita pendek biasanya memusatkan perhatian pada satu kejadian, mempunyai satu plot, setting yang tunggal, jumlah tokoh yang terbatas, mencakup jangka waktu yang singkat.

Tarigan (2010, hal. 3) menyatakan bahwa menulis merupakan suatu keterampilan berbahasa yang dipergunakan untuk berkomunikasi secara tidak langsung, tidak secara tatap muka dengan orang lain. Menulis merupakan suatu kegiatan yang produktif dan ekspresif. Pengertian menulis juga dikemukakan oleh Kurniawan \& Sutardi (2012, hal. 19) yang mengatakan bahwa menulis adalah mengungkapkan ide gagasan dalam pikiran dan rasa melalui bahasa. Seseorang dikatakan terampil menulis apabila ia memahami dan mengaplikasikan proses pengungkapan ide, gagasan, dan perasaan dalam bahasa tulis dengan mempertimbangkan faktorfaktor, antara lain ejaan dan tata bahasa, organisasi atau susuan tulisan, keutuhan (koherensi), kepaduan (kohesi), tujuan, dan sasaran tulisan.

Kompetensi menulis merupakan salah satu kompetensi yang harus dicapai secara tuntas. Kenyataannya, dalam pembelajaran menulis siswa masih menemui hambatan. Kurniawan (2012, hal. 63) menyatakan dunia kepenulisan merupakan dunia yang rumit dan kompleks. Menulis menuntut kesungguhan, keterampilan, kemampuan, dan keluasan pengetahuan. Kenyataan menunjukkan bahwa lebih mudah menyampaikan pikiran, perasaan, dan pengalaman secara langsung atau lisan dibandingkan dengan menyampaikannya secara tertulis.

Bahan ajar merupakan salah satu aspek penting dalam dunia pendidikan, karena bahan ajar merupakan salah satu sarana untuk mendukung berjalannya proses belajar. Widodo \& Jasmadi (dalam Lestari, 2013, hal. 1) menjelaskan bahwa bahan ajar adalah seperangkat sarana atau alat pembelajaran yang berisikan materi pembelajaran, metode, batasan-batasan, dan cara mengevaluasi yang didesain secara sistematis dan menarik dalam rangka mencapai tujuan yang diharapkan, yaitu mencapai kompetensi dan subkompetensi dengan segala kompleksitasnya.

Bahan ajar adalah seperangkat sarana atau alat pembelajaran yang berisikan materi pembelajaran, metode, batasanbatasan, dan cara mengevaluasi yang didesain secara sistematis dan menarik 
dalam rangka mencapai tujuan yang diharapkan, yaitu mencapai kompetensi atau subkompetensi dengan segala kompleksitasnya Widodo \& Jasmadi (dalam Lestari, 2013, hal. 1). Pengertian ini menjelaskan bahwa suatu bahan ajar haruslah dirancang dan ditulis dengan kaidah intruksional karena akan digunakan oleh guru untuk membantu dan menunjang proses pembelajaran. Bahan atau materi pembelajaran pada dasarnya adalah "isi" dari kurikulum, yakni berupa mata pelajaran atau bidang studi dengan topik/subtopik dan rinciannya.

Prastowo (2016, hal. 138) mengungkapkan bahwa bahan ajar merupakan segala bahan (baik informasi, alat, maupun teks) yang disusun secara sistematis, yang menampilkan sosok utuh dari kompetensi yang akan dikuasai peserta didik dan digunakan dalam proses pembelajaran dengan tujuan perencanaan dan penelaahan implementasi pembelajaran. Buku sebagai bahan ajar merupakan buku yang berisi ilmu pengetahuan hasil analisis terhadap kurikulum dalam bentuk tertulis. Buku disusun dengan menggunakan bahasa sederhana, menarik, dilengkapi gambar, keterangan, isi buku, dan daftar pustaka. Buku akan sangat membantu guru dan siswa dalam mendalami ilmu pengetahuan sesuai dengan mata pelajaran masingmasing.

Seiring dengan pemakaian kurikulum 2013, bahan ajar yang digunakan dalam pembelajaran, khususnya mata pelajaran bahasa Indonesia yang diproduksi oleh tim dari Kementerian Pendidikan dan Kebudayaan Republik Indonesia. Guru juga masih mengandalkan referensi dari bahan ajar dari sumber lain seperti internet. Selain itu, guru juga belum berkeinginan untuk mengembangkan bahan ajar baru dengan alasan keterbatasan waktu dan kurikulum yang digunakan selalu mengalami revisi.

Pengembangan bahan ajar ini diharapkan dapat meningkatkan minat dan kreativitas siswa dalam menulis cerpen. Selain itu modul menulis teks cerpen berdasarkan teknik storyboard dapat membantu guru dalam mengelola pembelajaran yang efektif dan efisien, dan juga dapat menjadi referensi dalam pembelajaran menulis cerpen. Tujuan penelitian ini adalah untuk mengembangkan bahan ajar menulis teks cerpen berdasarkan teknik storyboard pada siswa kelas XI SMA, untuk mengetahui kelayakan bahan ajar menulis teks cerpen berdasarkan teknik storyboard pada siswa kelas XI SMA, dan untuk mengetahui keefektifan bahan ajar menulis cerpen berdasarkan teknik storyboard di kelas XI SMA.

Pemilihan teknik storyboard didasarkan pada kesesuaian teknik ini dengan materi menulis cerpen. Selain itu, teknik storyboard juga menggabungkan seni menggambar dalam proses menulis cerpen yang dapat menarik minat siswa dalam menulis cerpen. Teknik storyboard merupakan aktivitas sebelum menulis yang menekankan pada elaborasi (penjelasan yang detil), prediksi atau perkiraan, penumbuhan gagasan, dan pengurutan (Wiesendanger, 2009, hal. 161). Hal ini digunakan untuk memotivasi siswa dalam mengembangkan kemampuan menulis yang diawali dengan membuat kerangka karangan berupa gambar dan kemudian dikembangkan menjadi sebuah paragraf.

Teknik storyboard digunakan pada saat kegiatan sebelum menulis yang menekankan pada elaborasi (penjelasan yang detil), prediksi atau perkiraan, penumbuhan gagasan, dan pengurutan (Wiesendanger, 2009, hal. 161). Hal ini digunakan untuk memotivasi siswa untuk mengembangkan kemampuan diri dalam menulis yang diawali dengan membuat kerangka karangan berupa gambar dan kemudian dikembangkan menjadi sebuah paragraf. Teknik storyboard ini nantinya diterapkan dalam pembelajaran menulis cerpen. Teknik ini cocok untuk 
pembelajaran menulis cerpen karena dalam teknik ini menekankan pada elaborasi, prediksi atau perkiraan, penumbuhan gagasan, dan pengurutan. Teknik ini diawali dengan membuat beberapa ilustrasi gambar yang kemudian setiap ilustrasi gambar tersebut dikembangkan menjadi sebuah paragaraf sehingga menjadi sebuah cerita yang utuh.

Langkah-langkah teknik storyboard di atas dilakukan sebuah modifikasi untuk memudahkan siswa dalam memahami langkah tersebut. Langkah-langkah teknik storyboard setelah dimodifikasi adalah (1) siswa membagi selembar kertas menjadi beberapa bagian, (2) siswa mencari gagasan tentang ide-ide cerita dan menggambar peristiwa awal dan akhir pada bagian pertama dan terakhir dari kertas tersebut, (3) siswa mengembangkan idenya dengan mengisi bagian-bagian yang tersisa dalam urutan yang sesuai, (4) siswa memeriksa urutan cerita, lalu mengoreksi draf pertama yang mereka buat, (5) siswa menambahkan kata-kata pada gambar mereka dan membuat kerangka finalnya, (6) siswa mengubah kata-kata pada setiap gambar menjadi sebuah teks cerita, dan (7) siswa dapat membagi cerita dengan siswa lain.

Keunggulan teknik storyboard adalah penggunaan gambar dalam proses menulis cerpen, berbeda dengan kerangka karangan yang umum digunakan. Menggambar dapat menambah kreativitas siswa dalam mengembangkan ide. Karena gambar merupakan perangkat pembelajaran yang sangat menarik minat belajar siswa. Selain itu, teknik storyboard juga dapat memudahkan siswa dalam menentukan cerita tanpa keluar dari ide utamanya.

\section{B. METODE}

Penelitian ini merupakan penelitian pengembangan atau Research \& Development (R\&D). Research and Development adalah model penelitian yang digunakan untuk menghasilkan produk tertentu dan menguji keefektifan produk tersebut (Sugiyono, 2012, hal. 104). Penelitian dan pengembangan merupakan metode penelitian yang digunakan untuk mengembangkan atau memvalidasi produk-produk yang digunakan dalam pendidikan dan pembelajaran. Uji validasi bahan ajar diberikan kepada guru ahli materi dan ahli media hasil penilaian oleh ahli materi digunakan untuk mengetahui kevalidan bahan ajar yang dikembangkan berdasarkan aspek kelayakan isi/materi, kelayakan penyajian, kelayakan kebahasaan.dan kelayakan kegrafikan. Lembar penilaian perangkat pembelajaran menggunakan skala likert $1-5$ dengan kriteria Sangat Kurang (SK), Kurang (K), Cukup (C), Baik (B), dan Sangat Baik (SB) yang telah dinyatakan valid dan layak (Hamalik, 2007, hal. 57). Keterapan modul dalam pembelajaran didapatkan dari data aktivitas siswa saat pembelajaran di kelas, aktivitas siswa saat diskusi, dan aktivitas siswa saat praktikum. data aktivitas siswa dianalisis dengan menghitung nilai rata-rata dari ketiga aktivitas siswa

\section{PEMBAHASAN}

Hasil validasi ahli media di atas, diperoleh data skor rata-rata hasil validasi tahap 1 dan 2 sebagai berikut. 
Tabel 1. Data Skor Rata-Rata Validasi Dosen Ahli Materi pada Keseluruhan Aspek

\begin{tabular}{clcc}
\hline No. & \multicolumn{1}{c}{ Aspek Penilaian } & Skor Rata-Rata & Persentase \\
\hline 1. & Kelayakan isi/materi & 4,42 & $88,4 \%$ \\
2. & Kelayakan penyajian & 4,63 & $92,5 \%$ \\
3. & Kelayakan bahasa & 4,33 & $86,67 \%$ \\
4. & Kelayakan kegrafikan & 4,73 & $94,55 \%$ \\
\hline & Jumlah & $\mathbf{1 8 , 1 1}$ & $\mathbf{3 6 2 , 1 2 \%}$ \\
& Rata-rata & $\mathbf{4 , 5 3}$ & $\mathbf{9 0 , 5 3 \%}$ \\
\hline
\end{tabular}

Pada tabel tersebut dapat diketahui peningkatan yang cukup signifikan validasi rata-rata pada yaitu 44,53 dengan rata-rata prosentase sebesar $90,53 \%$ dengan kategori "sangat baik".

Tabel 2. Data Skor Rata-Rata Validasi Ahli Media pada Keseluruhan Aspek

\begin{tabular}{cclcc}
\hline Tahap & No. & \multicolumn{1}{c}{ Aspek Penilaian } & Skor Rata-Rata & Persentase \\
\hline 1 & 1. & Kelayakan isi/materi & 3,11 & $62,11 \%$ \\
& 2. & Kelayakan penyajian & 3,25 & $65 \%$ \\
& 3. & Kelayakan bahasa & 2,83 & $56,67 \%$ \\
& 4. & Kelayakan kegrafikan & 3,18 & $63,63 \%$ \\
& & Jumlah & $\mathbf{1 2 , 3 7}$ & $\mathbf{2 6 7 , 7 1 \%}$ \\
& & Skor Rata-rata & $\mathbf{3 , 0 9}$ & $\mathbf{6 1 , 8 5 \%}$ \\
& & & & \\
& 1. & Kelayakan isi/materi & 4,63 & $92,63 \%$ \\
& 2. & Kelayakan penyajian & 4,63 & $92,5 \%$ \\
& 3. & Kelayakan bahasa & 4,67 & $93,33 \%$ \\
& 4. & Kelayakan kegrafikan & 4,72 & $94,54 \%$ \\
& & Jumlah & $\mathbf{1 8 , 6 5}$ & $\mathbf{3 7 3} \%$ \\
& & Skor Rata-rata & $\mathbf{4 , 6 6}$ & $\mathbf{9 3 , 2 5 \%}$ \\
\hline
\end{tabular}

Berdasarkan data pada tabel di atas, hasil skor yang diperoleh pada tahap pertama berjumlah 12,37 dengan skor rata-rata 3,09 atau 61,85\% dan berkategori "baik", sedangkan jumlah skor yang diperoleh dari tahap kedua yaitu 18,65 dengan skor rata-rata 4,66 atau 93,25\% dan berkategori "sangat baik".

Modul merupakan bahan ajar yang ditulis dengan tujuan agar siswa dapat belajar secara mandiri tanpa atau dengan bimbingan guru. Oleh karena itu, modul harus berisi tentang petunjuk belajar yang akan dicapai, isi materi pelajaran, informasi pendukung, latihan soal, petunjuk kerja, evaluasi, dan balikan terhadap hasil evaluasi (Prastowo, 2016, hal. 104). Modul berjudul "Menulis Teks Cerpen Berdasarkan Teknik Storyboard untuk Siswa SMA Kelas XI" disusun berdasarkan pada empat aspek kelayakan. Aspek tersebut antara lain isi/materi, penyajian, bahasa, dan kegrafikan.

Aspek kebahasaan dalam modul menulis teks cerpen berdasarkan teknik storyboard menggunakan bahasa yang bersahabat/akrab (user friendly). Daryanto (2013, hal. 11) menjelaskan bahwa salah satu bentuk bahasa yang bersahabat/akrab adalah setiap instruksi dan paparan informasi yang ditampilkan bersifat membantu dan bersahabat dengan pemakainya, termasuk kemudahan pemakai dalam merespon dan mengakses sesuai dengan keinginan. Penggunaan bahasa yang sederhana, mudah dimengerti, serta menggunakan istilah yang umum digunakan. Bahasa yang akrab dalam modul menulis teks cerpen berdasarkan teknik storyboard. 


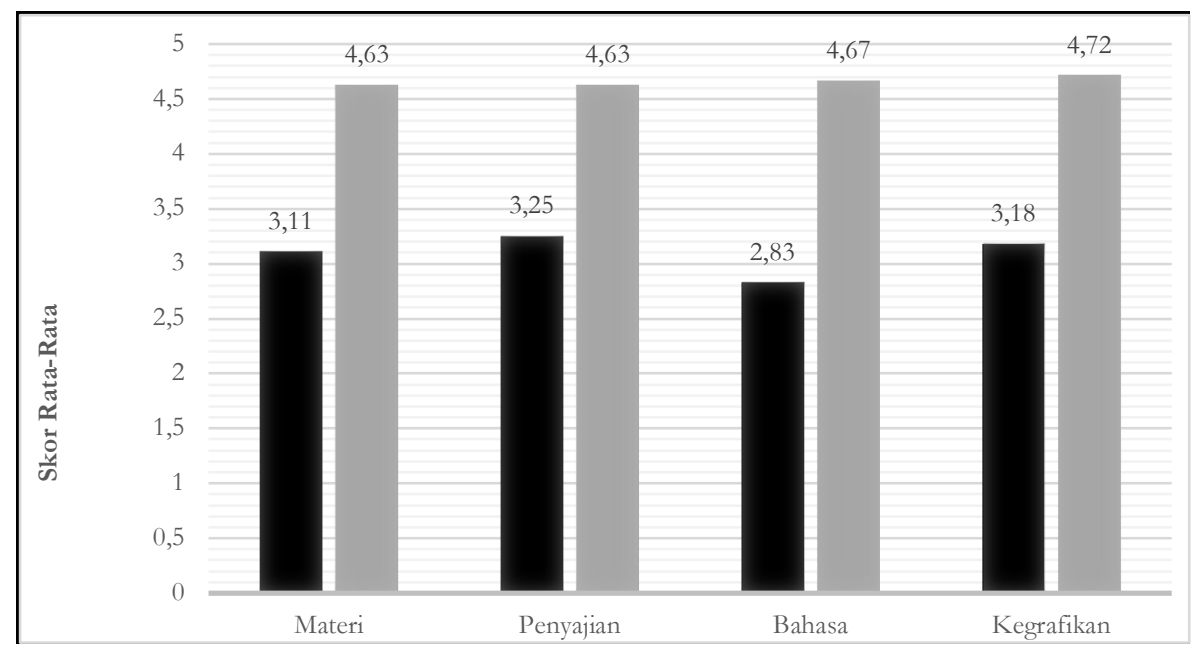

\section{Gambar 1. Grafik Penilaian Ahli Media}

Berdasarkan grafik di atas, dapat diketahui perbedaan skor rata-rata yang diperoleh pada tahap pertama dan kedua. Perbedaan ini dikarenakan produk yang divalidasi pada tahap pertama belum dilakukan revisi, sedangkan validasi pada tahap kedua sudah dilakukan revisi. Pada tahap pertama, aspek penilaian yang memperoleh skor rata-rata paling rendah adalah aspek penyajian yang memperoleh skor rata-rata 3,11, aspek kebahasaan 2,83 dan aspek kegrafikan yang memperoleh skor rata-rata 3,18. Setelah dilakukan revisi/perbaikan, skor rata-rata pada validasi tahap dua mengalami peningkatan. Aspek kebahasaan, penyajian dan kegrafikan yang pada tahap pertama mendapatkan nilai rendah mengalami peningkatan. Pada validasi tahap kedua, aspek kebahasaann memperoleh skor ratarata 4,67, aspek penyajian 4,63 sedangkan aspek kegrafikan memperoleh skor ratarata 4,72 .

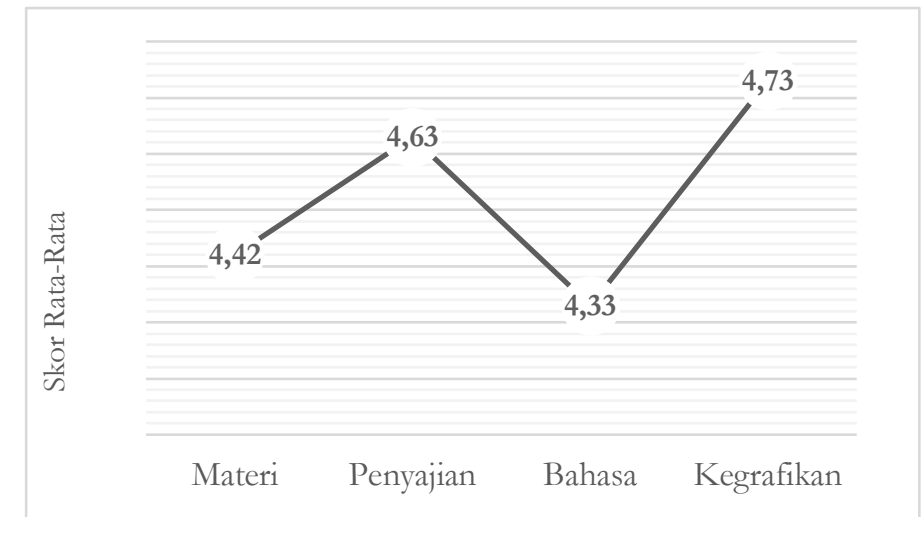

\section{Gambar 2. Grafik Penilaian Ahli Bahasa}

Grafik di atas menunjukkan hasil validasi ahli materi Bahasa Indonesia terhadap modul menulis teks cerpen berdasarkan teknik storyboard dengan skor rata-rata terendah adalah aspek bahasa dengan skor 4,33. Sedangkan aspek penilaian yang memperoleh skor tertinggi adalah aspek kegrafikan memperoleh skor rata-rata 4,73. Selain memberikan penilaian terkait kelayakan modul, ahli 
Bahasa Indonesia juga memberikan saran perbaikan terhadap modul yang dikembangkan.

\section{PENUTUP}

Pengembangan bahan ajar menulis teks cerpen ditulis denhan tujuan agar siswa dapat belajar secara mandiri tanpa atau dengan bimbingan guru. Bahan ajar harus berisi tentang petunjuk belajar yang akan dicapai, isi materi pelajaran, informasi pendukung latihan soal, petunjuk kerja, evaluasi dan hasil terhadap evaluasi yang disusun berdasarkan aspek kelayakan. Kelayakan hasil pengembangan bahan ajar menulis teks cerpen berdasarkan teknik storyboard dilakukan validasi oleh ahli materi dan ahli media mencakup aspek kelayakan isi/materi, kelayakan penyajian, kelayakan kebahasaan dan kelayakan kegrafikan. Keempat aspek diakumulasikan, bahan ajar menulis teks cerpen berdasarkan teknik storyboard memperoleh skor rata-rata sebesar 4,45 dengan persentase kelayakan sebesar $89 \%$. Dengan criteria sangat baik dan sangat layak digunakan. Keefektifan bahan ajar bahan ajar menulis teks cerpen berdasarkan teknik storyboard dimulai dengan pengalaman awal siswa dalam menulis teks cerpen dilakukan oleh 28 siswa memperoleh skor rata-rata sebesar 4,22 atau 84,44\% dengan criteria sangat baik, yang mencakup aspek kelayakan isi/materi, kelayakan penyajian, kelayakan kebahasaan dan kelayakan kegrafikan. Dengan demikian maka bahan ajar sangat efektif untuk digunakan sebagai modul pembelajaran di SMA kelas XI.

\section{DAFTAR PUSTAKA}

Daryanto. (2013). Menyusun Modul Baban Ajar untuk Persiapan Guru Dalam Mengajar. Yogyakarta: Gaya Media.

Hamalik, O. (2007). Proses Belajar Mengajar. Jakarta: Bumi Aksara.
Himang, V. H. (2019). Pengembangan Bahan Ajar Menulis Cerpen Berbasis Pengalaman Siswa Kelas XI SMK. Diglosia: Jurnal Kajian Bahasa, Sastra, Dan Pengajarannya, 2(2), 93-102. http://diglosiaunmul.com/index.p $\mathrm{hp} /$ diglosia/article/view/21

Khulsum, U., Hudiyono, Y., \& Sulistyowati, E. D. (2019). Pengembangan Bahan Ajar Menulis Cerpen dengan Media Storyboard pada Siswa Kelas X SMA. Diglosia: Jurnal Kajian Bahasa, Sastra, Dan Pengajarannya, 1(1), 1-12. http://diglosiaunmul.com/index.p $\mathrm{hp} /$ diglosia/article/view/4

Kurniawan, H. \& Sutardi. (2012). Penulisan Sastra Kreatif. Yogyakarta: Graha Ilmu.

Lestari, I. (2013). Pengembangan Bahan Ajar Berbasis Sesuai dengan Kurikulum Satuan Pendidikan. Padang: Akademia Permata.

Muhibin, S. (2009). Psikologi Pendidikan dengan Pendekatan Baru. Bandung: Remaja Rosdakarya.

Prastowo, A. (2016). Panduan Kreatif Membuat Bahan Ajar Inovatif. Yogyakarta: Diva Press.

Sugiyono. (2012). Metode Penelitian Pendidikan (Pendekatan Kuantitatif, Kualitatif, dan ReDD). Bandung: Alfabeta.

Tarigan, H. G. (2010). Menulis sebagai Suatu Keterampilan Berbahasa. Edisi Revisi. Bandung: Angkasa.

Vembriarto. (2008). Pengantar Modul. Yogyakarta: Yayasan Pendidikan Paramita.

Wiesendanger, K. D. (2009). Strategies for Literacy Education. Ohio: Merill Prentice Hall.

Winkel. (2005). Psikologi Pengajaran. Jakarta: Gramedia. 